\title{
Catalase Activity and Hydrophobicity Test of Bacteria Susceptible to Extracts of Cleistopholis Patens and Piliostigma Reticulatum
}

\author{
A. O. Daniels, Taye Temikotan, A.O. Akinkugbe, and D. Ibiyemi
}

\section{ABSTRACT}

Antibacterial effect of the ethanol, methanol and ethyl acetate extracts of Piliostigma reticulatum and Cleistopholis patens on ten pathogenic bacteria including Pseudomonas aeruginosa, Salmonella typhi, Escherichia coli, Proteus vulgaris, Streptococcus pyogenes, Klebsiella aerogenes, Staphylococcus aureus, Serratia marscences, Yersinia enterocolitica and Shigella dysenteriae was investigated. Survival rate after treatment was investigated. Cell surface hydrophobicity after treatment was tested and the catalase activities of the plant extracts were determined. The results revealed that at $100 \mathrm{mg} / \mathrm{ml}$ of extracts, the ethanol extracts of $C$. patens showed antibacterial activities against $S$. typhi, $P$. vulgaris, Str. pyogenes, $K$. aerogenes, Saureus and Yersinia enterocolitica with zones of inhibition of $18 \mathrm{~mm}, 14 \mathrm{~mm}, 18 \mathrm{~mm}, 24 \mathrm{~mm}, 14 \mathrm{~mm}$ and $18 \mathrm{~mm}$ respectively and the ethyl acetate extract was active against Sal. typhi, $P$. vulgaris, Str. pyogenes, $K$. aerogenes, $S$. aureus Ser. marscences and $Y$. enterocolitica with zones of inhibition of $14 \mathrm{~mm}, 22 \mathrm{~mm}, 18 \mathrm{~mm}, 18 \mathrm{~mm}, 14 \mathrm{~mm}$, $16 \mathrm{~mm}$ and $16 \mathrm{~mm}$ respectively while ethanol extract of $P$. reticulatum showed activity against $P$. aeruginosa, Sal. typhi, E.coli, Str. pyogenes, K. aerogenes, S. aureus, and Sh. dysenteriae with zones of inhibition of $13 \mathrm{~mm}, 12 \mathrm{~mm}, 10 \mathrm{~mm}$, $10 \mathrm{~mm}, 8 \mathrm{~mm}, 10 \mathrm{~mm}$ and $14 \mathrm{~mm}$ respectively. The ethyl acetate was active against E.coli, Str. pyogenes, $K$. aerogenes, S. aureus and Sh. dysenteriae respectively. The methanol extract had no activity against the test organisms. The kill- time curve showed that susceptible cells die after 10 and 20 minutes after contact with the extracts of $\mathrm{C}$. patens for most of the test bacteria while cell death occurred at 10, 20, 40, 50 and 60 min after contact. The hydrophobicity test showed that test organisms had hydrophobicity of between $47 \%$ and $99 \%$ in the extracts. Catalase production reduced considerably in some bacteria after treatment with plant extracts. The results obtained presupposes that the plant extracts are effective against some of the test organisms and their mode of activity are is that they interfere with the ability of bacteria to produce catalase, inducing cell death by the production of hydroxyl radical and also by to the enhancement of non-opsonic phagocytosis of bacteria by macrophages.

Keywords: Catalase activity, Hydrophobicity, Kill-time kinetics, Piliostigma reticulatum.

\section{INTRODUCTION}

Microbial adhesion to eukaryotic cells seems to be the first stage in many bacterial infections [1] Cell surface hydrophobicity is often associated with the binding of bacterial cells to specific cells and tissues receptors of the mucosa surface of the infected host. The cell surface hydrophobicity, surface charge, acid- base properties and surface topography can have significant effect on microbial adhesion [2]-[4].

Adhesion of bacterial cells to surface and bioflim formation depend on the properties of bacterial cells, environmental factors influencing their growth and on the properties of the material to which they adhere [5], but mainly governed by the electrostatic, Van der waal, hydrophobic and contact interaction [6].
Published Online: June 13, 2020

ISSN: 2684-5199

DOI : $10.24018 /$ ejbio.2020.1.3.18

\section{A. O. Daniels*}

Department of Biological Sciences, Achievers University, Owo, Ondo State, Nigeria.

(email: toyosidanny@yahoo.com)

T. Temikotan

Department of Biological Sciences, Achievers University, Owo, Ondo State, Nigeria.

A. O. Akinkugbe

Department of Biological Sciences,

Achievers University, Owo, Ondo State,

Nigeria.

D. Ibiyemi

Department of Chemical Sciences, Achievers University, Owo, Ondo State, Nigeria.

*Corresponding Author
High cell surface hydrophobicity enables microorganisms to attach to hydrocarbon droplets on the surface of cells and to move from water to organic, hydrocarbon phase where biosurfactants and enzymes decompose water [7]. The rapid change in environmental condition forces adaptive features on microorganisms which enhances its ability to survive. One of this mechanism is the release of outer membrane vesicle (MV) in Gram negative bacteria causing a significant increase in cell surface hydrophobicity and an enhanced tendency to form biofilms [8].

Catalase production by microbes is a mechanism by which these organisms cleave $\mathrm{H}_{2} \mathrm{O}_{2}$ to produce water $\left(\mathrm{H}_{2} \mathrm{O}\right)$ and oxygen $\left(\mathrm{O}_{2}\right)$, thereby neutralizing the bactericidal effects of antimicrobials [9]. Phagocytes often use oxygen dependent mechanisms to prevent bacterial infections; $\mathrm{O}^{-}$and 
$\mathrm{H}_{2} \mathrm{O}_{2}$ are some weapons used by phagocytes to kill bacteria [9]. Medicinal plants have been known to use several mechanisms in their killing pattern including disruption of membrane potential, inner membrane permeabilization, blebbing and leakage of cellular content [10]. Several plant derived extracts or active compounds can prevent the attachment of pathogens but little is known about their effects on bacterial adhension [11].

The main objective of this study is to investigate the antibacterial activity and the effects of extracts of Piliostigma reticulatum and Cleistopholis patens on the hydrophobicity and the catalase producing ability of ten bacteria.

\section{MATERIALS AND METHODS}

\section{A. Plant Sampling and Preparation}

Stem bark of plants were sampled from private garden of a traditional healer at Ibode in Ibadan, Oyo State. The plants were identified by Mr Omotayo of the Department of Plant Science and Biotechnology, Ekiti State University, Ekiti State. Voucher specimens with voucher numbers WHAE2017/001 and WHAE2017/002 were deposited in the herbarium of the Ekiti State University, Ado- Ekiti.

The ethanol, methanol and ethyl acetate extracts were prepared by dissolving $200 \mathrm{gm}$ amount of powdered plant samples in $500 \mathrm{mls}$ of each solvent. The solutions were allowed to stand for 5 days $(120 \mathrm{hr})$ at room temperature of $27^{\circ} \mathrm{C} \pm 1^{\circ} \mathrm{C}$, after which each solution was filtered using a sterile muslin cloth and a Whatmann no 1 filter paper as described by Fabricant and Fansworth (2001). The collected filtrate was evaporated to dryness under sterile condition at room temperature $\left(27^{\circ} \mathrm{C}\right)$.

The extracts were kept in sterile bottles until ready for use.

\section{B. Collection and Maintenance of Microorganisms:}

Clinical samples of microorganisms were collected from the Microbiology Department of Obafemi Awolowo University, Ile-Ife, Osun State. The strains were confirmed by biochemical tests and maintained on agar slants.

\section{Determination of Antibacterial Activity of Plant Extract:}

A five (5) gram portion of the plant solvent (ethanol, methanol and ethyl acetate) extracts was reconstituted in $5 \mathrm{mls}$ of $50 \%$ Dimethyl sulfoxide (DMSO) to make a stock solution of $100 \mathrm{mg} / \mathrm{ml}$ of extracts. The agar well diffusion method of Perez, (1990) was adopted for the antibacterial assay. Test organisms were suspended in nutrient broth and incubated for 4 hours to obtain a concentration corresponding to McFarlands constant $\left(0.5 \times 10^{8} \mathrm{cfu} / \mathrm{ml}\right)$. The inoculum was standardized with barium sulphate. The sterile petri-plates were inoculated by pour plate method. One $\mathrm{ml}(1 \mathrm{ml})$ of the test organisms was pipetted aseptically into each petri dish and about $20 \mathrm{ml}$ of sterilized nutrient agar was poured into the petri dish containing the inoculum. The agar plates were allowed to set. Wells of $6 \mathrm{~mm}$ diameter were punched over the agar plates equidistant from each other using sterile cork borer and $0.5 \mathrm{ml}$ of each plant extracts of different concentrations as prepared by the serial dilution were added to the wells using a micropippette. The extracts were allowed to diffuse into the agar for about $20 \mathrm{mins}$ after which the plates were incubated for $24 \mathrm{~h}$ at $37^{\circ} \mathrm{C}$. After incubation the diameter of inhibitory zones formed around each wells were measured in mm and recorded. Experiments were carried out in triplicates and the average values recorded.

\section{Determination of The Survival Rate of Test Organisms in Plant Extracts.}

To evaluate the survival rate of test organisms in the extracts, $2 \mathrm{ml}$ of inoculum at a concentration of $0.5 \times 10^{8} \mathrm{cfu} /$ $\mathrm{ml}$ was added to a test tube containing $100 \mathrm{mg} / \mathrm{ml}$ of the extracts and plated on nutrient agar. Colony count (CFU) was determined after $0,5,10,15,20,30,40,50,60,80,90,100$, and $110 \mathrm{~min}$ of incubation at $37^{\circ} \mathrm{C}$. At each incubation time, about $0.5 \mathrm{ml}$ of solutions were plated at $37^{\circ} \mathrm{C}$ for $24 \mathrm{hr}$. After this period, the colonies were counted and the kinetic action curve was constructed.

\section{E. Determination of Hydrophobicity of Test Organisms After Treatment With Plant Extracts.}

A slightly modified method as described by Rosenberg et al., [13] was adopted in this test. A $2 \mathrm{ml}$ portion of bacteria culture was centrifuged at 5000rpm for 4 minutes then washed with phosphate buffer saline (PBS). The cells were resuspended in $15 \mathrm{~m}$ of PBS and the absorbance (Ao) measured at $620 \mathrm{~nm}$ using spectrophotometer (T 70 UV-VIS Spectrometer, PG Instruments Ltd.). A $0.5 \mathrm{ml}$ portion of xylene was added to $3.5 \mathrm{ml}$ of bacterial suspension in PBS and the mixture agitated on a vortex at 2500 twiddles/min for 20min. The optical density (A) of the aqueous phase was measured and recorded. Percentage bacterial cells in the xylene layer was calculated as percentage hydrophobicity using the equation

$\%$ hydrophobicity $=(1-(\mathrm{A})) \times 100$

Ao

Where $\mathrm{A}$ is the absorbance of bacterial cells in PBS and Ao is the absorbance of cells in PBS after treatment with xylene. After treatment with plant extracts, Ao is the absorbance of cells in PBS after treatment with plant extracts and the results compared with the result of cells in xylene. Statistical analysis using the T- test was carried out on the result.

\section{F. Evaluation of The Specific Catalase Production of Test Organism in Plant Extract.}

Catalase production was measured by the time required for culture-soaked filter paper disks to float to the surface of a $1 \%$ hydrogen peroxide solution, based on the protocol used by Hsieh et al [14] and Chan et al [15]. A 1\% (v/v) hydrogen peroxide solution was prepared from the $30 \%$ stock solution. $16 \mu$ of test culture was absorbed onto $5 \mathrm{~mm}$ disks of $3 \mathrm{~mm}$ filter paper (\#3 Whatman) for 10sec before being dropped into $50 \mathrm{ml}$ of $1 \%(\mathrm{v} / \mathrm{v}) \mathrm{H}_{2} \mathrm{O}_{2}$, which was approximately $3 \mathrm{~cm}$ of liquid height in a $100 \mathrm{ml}$ beaker. Catalase activity was determined as the inverse of the time taken for the disk to float to the top. Disks that sank to the bottom or clung to the walls of the beaker were disregarded and the samples repeated. Also, turbidity measurements of the original culture were used to normalize the data so that it reflected specific catalase activity to account for differences in catalase production. The same procedure was repeated with culture treated with plants' extracts and the results recorded. 


\section{RESULTS}

Cleistopholis patens showed antibacterial activities against some of the test organisms at $100 \mathrm{mg} / \mathrm{ml}$ with the ethanol extract showing a zone of inhibition of $18 \mathrm{~mm}, 14 \mathrm{~mm}, 18 \mathrm{~mm}$, $24 \mathrm{~mm} 14 \mathrm{~mm}$ and $16 \mathrm{~mm}$ against $S$. typhi, P. vulgaris, $S$. pyogenes, $K$. aerogenes, $S$. aureus and $Y$. enterocolitica respectively. The ethyl acetate extracts showed activity against $S$. typi, $P$. vulgaris, $S$. pyogenes, $K$. aerogenes, $S$. aureus, $S$. marscences, and $Y$. enetrocolitica with zone of inhibition of $14 \mathrm{~mm}, 22 \mathrm{~mm}, 18 \mathrm{~mm}, 18 \mathrm{~mm}, 14 \mathrm{~mm}, 16 \mathrm{~mm}$ and $16 \mathrm{~mm}$ respectively.

Comparatively, the ethanol extract of Piliostigma reticulatum showed antibacterial activities against $P$. aeruginosa, $S$. typhi, $S$. pyogenes, $K$. aerogenes, $S$. aureus, and $S$. dysenteriae. With zones of inhibition of $13 \mathrm{~mm}, 12 \mathrm{~mm}$, $10 \mathrm{~mm}, 10 \mathrm{~mm}, 8 \mathrm{~mm}, 10 \mathrm{~mm}$, and $14 \mathrm{~mm}$ respectively while the ethyl acetate extract showed zones of inhibition of $16 \mathrm{~mm}$, $18 \mathrm{~mm}, 10 \mathrm{~mm}, 16 \mathrm{mmm}$ and $20 \mathrm{~mm}$ against E.coli, S.pyogenes, $K$. areogenes, $S$. aureus, and $S$. dysenteriae respectively. Methanol extracts of the two plants showed no antibacterial activity against the test organisms (Table I).

\section{A. Survival Rate of Test Bacteria}

Fig (1a) demonstrates that the number of viable cells decreased in proportion to the exposure time of microorganisms to the ethanol extract of Piliostigma reticulatum. At first contact ( $0 \mathrm{~min}$ ) with the extract, the cell population was high, but as more time elapsed, there was a corresponding decrease in bacteria population, which reduced the logarithmic cycle and highlights the potent bactericidal action of this compound. Interestingly, the times required for the total kill of the bacterial cells were not significantly different among the two plant extract.
When evaluating the survival rate of test bacteria to plant extract against $S$. pyogenes and $S$. aureus, (Figs 1 and 2 ), it was observed that cell death occurred in only $30 \mathrm{~min}$ after contact of $S$. pyogenes with $C$. patens while cell death occurred at $40 \mathrm{~min}$ after exposure for $S$. aureus. When the cells were treated at 40 and $50 \mathrm{~min}$, respectively, the same bactericidal effect was experienced. The extracts from $C$. patens plants were able to significantly reduce the number of cells just after $30 \mathrm{~min}$, while in the control, cells did not stop growing. After 50mins of contact with $C$. patens, no growth was recorded for Staphylococcus aureus, Streptococcus pyogenes, Salmonella typhi and Klebsiella aerogenes. For Piliostigma reticulatum, the same survival was recorded as that found with Cleistopholis patens. For most of the test organisms, reduction in microbial viablity started at about 20 minutes after contact, however, for Salmonella typhi, Klebsiella aerogenes and Shigella dysenteriae, cell death occurred at 40 minutes after contact with the extract. The log value of time-kill values showed cell death to have occurred at 20min after exposure for Staphylococcus aureus and Shigella dysenteriae.

However, there was no decrease in density of Shigella dysenteriae, E.coli Pr. vulgaris and Ps. aeruginosa in $C$. patens and Pr. vulgaris and Ps, aeruginosa in P. reticulatum. Interestingly, the times required for the total kill of the bacterial cells were significantly different among the two extracts evaluated.

\section{B. Catalase Production of Test Organisms}

$Y$. enterocolitica and Seratia merscences were catalase negative while the other test organisms were catalase positive. When these organisms were subjected to plant extracts, some of them lost their catalase status and the catalase positive organisms became catalase negative

TABLE I: Antibacterial activity of plant extracts against test organisms (in $\mathrm{mm}$ )

\begin{tabular}{|c|c|c|c|c|c|c|}
\hline & \multicolumn{3}{|c|}{ Cleistopholis patens } & \multicolumn{3}{|c|}{ Piliostigma reticulatum } \\
\hline & Ethanol & Methanol & E.acetate & Ethanol & Methanol & E..acetate \\
\hline P. aeruginosa & - & - & - & 13 & - & - \\
\hline S. typhi & 19 & - & 14 & 12 & - & - \\
\hline E.coli & - & - & - & 10 & - & 16 \\
\hline P. vulgaris & 14 & - & 22 & - & - & - \\
\hline S. pyogenes & 18 & - & 18 & 10 & - & 18 \\
\hline K. aerogenes & 24 & - & 18 & 8 & - & 10 \\
\hline S. aureus & 14 & - & 14 & 10 & - & 16 \\
\hline S.. merscences & - & - & 16 & - & - & - \\
\hline Y. enterocolitica & 18 & - & 16 & - & - & - \\
\hline S. dysenteriae & - & - & - & 14 & - & 20 \\
\hline
\end{tabular}


)

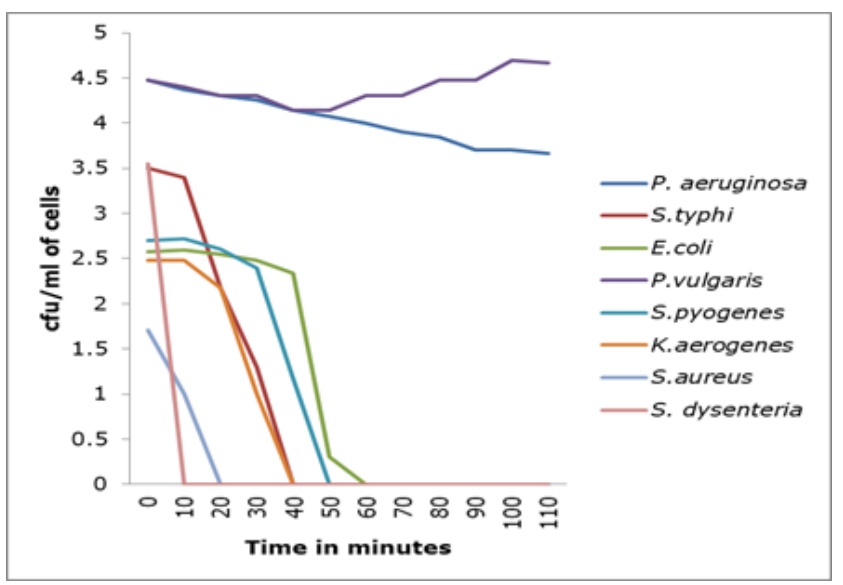

(a)

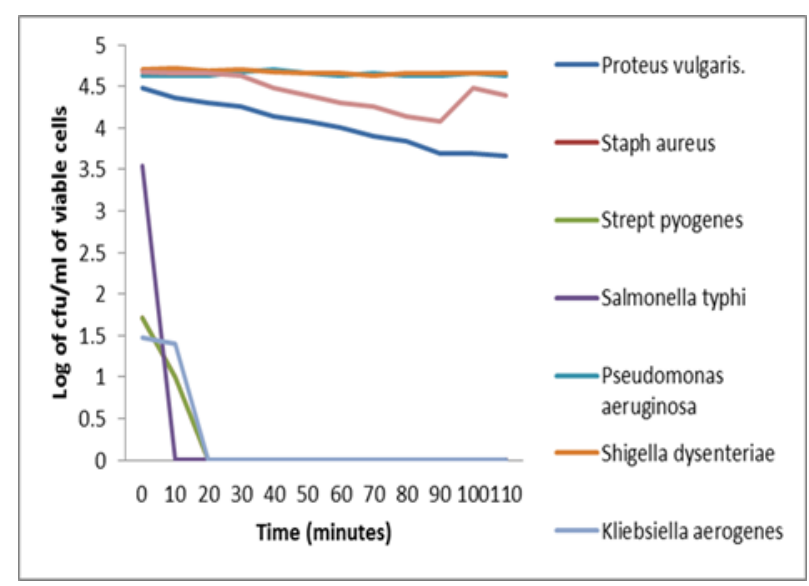

(b)

Fig. 1. (a) Survival curve of bacteria subjected to ethyl acetate extract of Piliostigma reticulatum, (b) shows Survival curve of bacteria subjected to ethyl acetate extract of Cleistopholis patens

while the catalase negative organisms retained their negative status. Pseudomonas aeruginosa, Shigella dysenteriae and Escherichia coli retained their ability to produce catalase after treatment.

These organisms were resistant to the solvent extracts of Cleistopholis patens as recorded in table 1. Figure 2(a) presents the catalase production abilities of the test organism before and after treatment with the extracts of Cleistopholis patens at $100 \mathrm{mg} / \mathrm{ml}$ of extract. It shows the inverse values of the time it took each paper disk to float on the surface of the $1 \%$ of hydrogen peroxide $\left(\mathrm{H}_{2} \mathrm{O}_{2}\right)$.

For the solvent extracts of Piliostigma reticulatum (Fig 2b), Staph aureus, Sal. typhi, Str. pyogenes ,K. aerogenes, Yer. enterocolitica, and Pr. vulgaris produced catalase in ethanol and methanol extracts, but not in ethyl acetate extract, while Staph aureus, Salmonella typhi, Str. pyogenes, K, aerogenes, Yersinia enterocolitica and $P$. vulgaris were unable to produce catalase in the ethyl acetate extract.

The result of the statistical analysis carried out using the T-test showed that the catalase activity between the control (culture without extract treatment) and culture in ethanol extracts of Cleistopholis patens showed significant difference at $0.05 \%$ level of confidence $(\leq 0.05)$. The control versus the methanol extract treatment showed no significant difference at $0.05 \%$ level of confidence $(P \geq 0.05)$ while the ethyl acetate extract showed a significant difference at $0.05 \%$ level of confidence $(\leq 0.05)$.
The result of the statistical analysis carried out using the T-test showed that the catalase activity between the control (culture without extract treatment) and culture in ethanol extracts of Cleistopholis patens showed significant difference at $0.05 \%$ level of confidence $(\leq 0.05)$.

The control versus the methanol extract treatment showed no significant difference at $0.05 \%$ level of confidence $(P \geq 0.05)$ while the ethyl acetate extract showed a significant difference at $0.05 \%$ level of confidence $(\leq 0.05)$.

\section{A.Percentage Hydrophobicity of Test organisms before And After Treatment With Plant Extracts.}

The hydrophobicity of test organisms are presented in table II and III . The higher the percentage of hydrophobicity, the lower the water affinity. Ser. marscences, S. aureus and Yer. enterocolitica in xylene showed hydrophobicity of respectively $96 \%, 98 \%$ and $99 \%$ while the same organisms in ethyl acetate extract of C. patens had hydrophobicity of $79 \%$, $93 \%$ and $90 \%$ respectively.

. Other test organisms showed hydrophobicity of between $47 \%$ and $77 \%$ in xylene while in ethyl acetate extract of $C$. patens hydrophobicity ranged from $68 \%$ to $91 \%$. The test organisms in ethanol extract showed hydrophobicity of between $71 \%$ and $99 \%$ with Shigella dysenteriae having the highest percentage hydrophobicity. Test organisms on the other hand showed hydrophobicity of between $67 \%$ and $96 \%$ in ethyl acetate extract of Piliostigma reticulatum with $E$. coli showing the highest percentage hydrophobicity of $96 \%$.

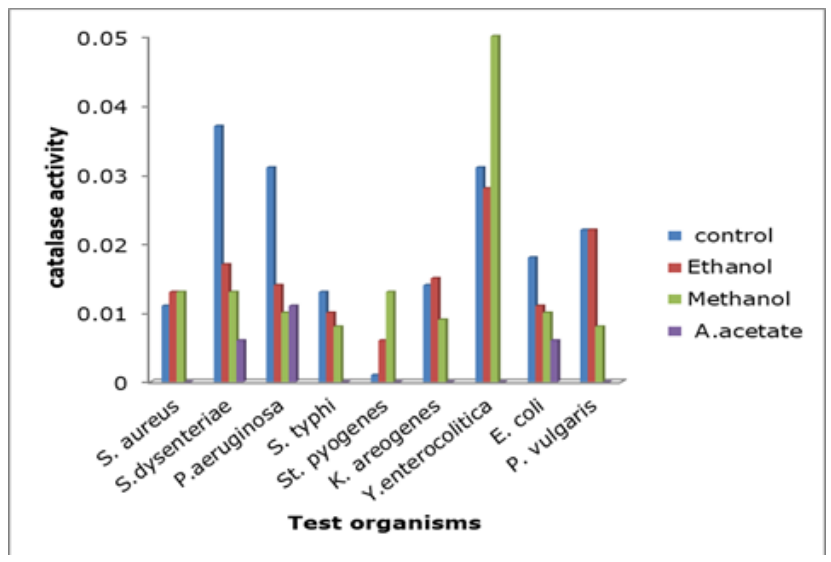

(a)

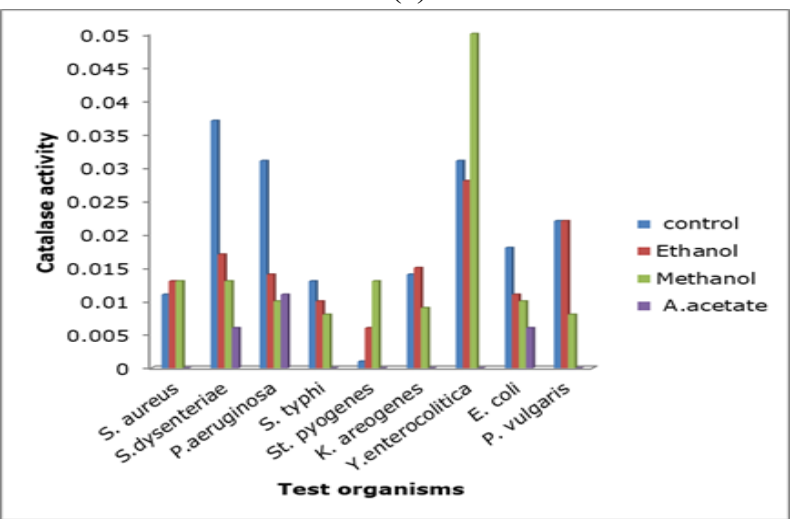

(b)

Fig. 2. (a) shows catalase activitybacteria subjected to ethyl acetate extract of Cleistopholis patens, (b) shows the catalase of bacteria subjected to ethyl acetate extract of Piliostigma reticulatum 
The test organisms in ethanol extract of Piliostigma reticulatum showed percentage hydrophobicity of between 67 and 98 with $S$. aureus and PS. aeruginosa showing the highest affinity of $98 \%$ each (Table III.)

Statistically, there was a significant difference between the hydrophobicity of test organisms in xylene and the hydrophobicity of test organisms in plant extracts at $0.05 \%$ level of significance $(\mathrm{P} \leq 0.05)$. The hydrophobicity in PBS versus test organisms in ethyl acetate extracts of $C$. patens (Table II) showed a significant difference at $0.05 \%$ level of confidence $(\mathrm{P} \leq 0.05)$. Similarly, the hydrophobic effect of test organisms in PBS was significantly different from the hydrophobic effect of test organisms in ethanol extract at $0.05 \%$ level of confidence $((\mathrm{P} \leq 0.05)$.

The Hydrophobic effect of test organisms in PBS against the hydrophobic effect of test organisms in the ethyl acetate extract of $P$. reticulatum showed a significant level of difference at $0.05 \%$ level of confidence $((\mathrm{P} \leq 0.05)$ (Table III). In the same vein, the hydrophobic effects of test organisms in PBS and organisms showed in ethanol extracts showed a significant difference at $0.05 \%(\mathrm{P} \leq 0.05)$

TABLE II: PERCENTAGE HYDROPHOBICITY OF ETHANOL AND ETHYL ACETATE EXTRACT OF C. PATENS

\begin{tabular}{|l|l|l|l|}
\hline Test organisns & xylene & ethanol & ethyl acetate \\
\hline S. aureus & 99 & 98 & 86 \\
\hline S. dysente & 51 & 67 & 67 \\
\hline P. aerugin & 56 & 98 & 83 \\
\hline S. typhi & 62 & 97 & 94 \\
\hline S. pyogenes & 77 & 79 & 80 \\
\hline K. areogenes & 47 & 84 & 75 \\
\hline Y.entero & 98 & 90 & 94 \\
\hline E. coli & 69 & 91 & 96 \\
\hline P. vulgaris & 67 & 88 & 89 \\
\hline S. marscenc & 96 & 84 & 89 \\
\hline
\end{tabular}

TABLE III: PERCENTAGE HYDROPHOBICITY OF ETHANOL AND ETHYL ACETATE EXTRACT OF P.RETICULATUM

\begin{tabular}{|l|l|l|l|}
\hline Test organisns & xylene & ethanol & ethyl acetate \\
\hline S. aureus & 99 & 98 & 86 \\
\hline S. dysente & 51 & 67 & 67 \\
\hline P. aerugin & 56 & 98 & 83 \\
\hline S. typhi & 62 & 97 & 94 \\
\hline S. pyogenes & 77 & 79 & 80 \\
\hline K. areogenes & 47 & 84 & 75 \\
\hline Y.entero & 98 & 90 & 94 \\
\hline E. coli & 69 & 91 & 96 \\
\hline P. vulgaris & 67 & 88 & 89 \\
\hline S. marscenc & 96 & 84 & 89 \\
\hline
\end{tabular}

\section{DISCUSSION}

Plants have been known from time immemorial to have antibacterial activities. This is evidenced in this study as the two plants used; $C$. patens and $P$. reticulatum both have broad spectrum antibacterial activities. Several authors have reported the antibacterial [16]- [17] anti-candidal activity [18] of C. patens. P. reticulum has been shown to possess antimicrobial and anti-inflammatory [16], Antispasmodic [19].antioxidant and antidiarrheal [20] properties. The report of this study confirms the status of the two plants as potent antibacterial as used by traditional medicine practitioners.

The survival curve of the test organisms after challenge with the plant extracts is a function of the ability of some microorganisms to tolerate antimicrobials. However, tolerance is seldom taken into consideration explicitly in healthcare as compared to resistance [21]. The success of antimicrobial therapy is determined by the complex interaction between an administered drug, a host and the infective agent. The time-kill curve reveals a time dependent antimicrobial effect of test plants. For the test bacteria, a short lag phase was experienced. A fast decline was observed for all the susceptible bacteria strains used reaching a very low phase only after $110 \mathrm{~min}$ after contact with test substance. In contrast, there was no significant difference in the population density of resistant bacteria like $S$. dysenteriae, E.coli, and $P$. aeruginosa in ethanol extract of $C$. patens as compared with the control. This is an indication that the plant could be bacteriostatic to the test bacteria since there was no significant increase in the density of bacteria cells.

However, in $P$. reticulatum, there was a considerable increase in the population of $P$. vulgaris while the population of $P$. aeruginosa remains constant. This study provides a fundamental information about the pharmacodynamics relationship between the antibacterial and the test bacteria. Ferro et al. [22] in their work were able to also establish the pharmacodynamic relationship between several antibiotics and Mycobacteria. Shami and Almasri [23] demonstrated from the time-kill curve obtained in their work that antimicrobial effect of antimicrobials is time and concentration dependent. They also posited that time-kill test is used to determine the bactericidal effect of antimicrobials. The result of this study shows that at $100 \mathrm{mg} / \mathrm{ml}$ of plant extract, the effect on susceptible bacteria is bactericidal. Microorganisms have various fascinating ways of resisting harmful antimicrobials. Genetic alterations in bacteria can cause resistance in one of four ways; i) Target molecules are structurally altered to prevent antibiotic binding; ii) antibiotics are excluded from cell entry; iii) They are inactivated through enzymatic degradation and ;iv) they are pumped out (efflux) [24]. Factors produced by microorganisms and that evoke diseases are known as the virulence factors. This include toxin production, surface coats that inhibit phagocytosis and surface receptors that bind to host cells. Hydrophobicity is the ability of organisms to repel water and attach to surfaces and it's a measure of bacterial virulence/ pathogenicity [25]. A significant increase in hydrophobicity is an adaptive reaction against antimicrobial agent [26]. However, high hydrophobicity of test organisms results in the enhancement of non-opsonic phagocytosis of bacteria by macrophages.

The treatment of bacteria with antibiotics induce increase in hydrophobicity and a decrease in negative charge of bacterial surface. Nomura et al., [27] suggested that an increase in hydrophobicity and a decrease in surface charge 
results in the non-opsonic phagocytosis of bacteria cells by macrophages which is observed in this study, an increase in hydrophobicity was observed in the susceptible bacteria when compared with hydrophobicity in xylene as presented in table 2 . This shows that non-opsonic phagocytosis could be a mode of action of the test plants used in this study.

The ability of bacteria to produce catalase contributes to their pathogenicity by detoxifying the oxygendepended microbicidal products of phagocytic cells. Low level of reactive oxygen species (ROS) such as hydrogen peroxide $\left(\mathrm{H}_{2} \mathrm{O}_{2}\right)$ are produced as a consequence of aerobic respiration and metabolism. Large concentration of $\mathrm{H}_{2} \mathrm{O}_{2}$ may overwhelm an organism's defenses and may prove fatal to microorganisms. Antimicrobials produce their killing effect by inducing the production of radicals within bacteria cells [28]. Research has also shown that antibiotic greatly induce oxidative stress in microbial cells [29]. So the loss of the ability to produce catalase by the test bacteria indicates the inability of bacteria to deactivate antimicrobial by catalase production. This is evidenced in this study with the correlation between catalase production and sensitivity of test organisms to plant extracts as presented in table 1 .

\section{CONCLUSION}

Conclusively, the plants $C$. patens and $P$. reticulatum have broad spectrum antimicrobial activities and they justify their uses in traditional treatment of microbial infections and as such can be considered as lead candidates in antimicrobial drug production.

\section{REFERENCES}

[1] R.. J. Gibbson, Bacterial attachment to host tissues in Infectious Diseases W.B. Saunders, Philadelphia. 1992: Pp 7-1

[2] P.C. Bernards, S.O. De Andrads, J.P.N. Ferreira, S.A., De-Araujo, F.A. Delatorre and I.M.P., Luiz Assessment of hydrophobicity and roughness of stainless steel adhered by an isolate of Bacillus cereus from a dairy plant. Brazillian Journal of Microbiology. 2010. 41.984992.

[3] S. El Abed., F. Hamadia , H., Latrache., M. Iraqui, and S.I. Koraichi. Adhesion of Aspergillus niger and Penicillium expansium pores on Fez cedar wood substrata. Annuals of Microbiology. 2010. 60.377-382.

[4] Q.C. Zhao,. C. Wang, Y. Liu. and S. Wang.. Bacterial adhesion on the metal-polymer composite coatings. International journal of Adhesion Adhesives. 2007. 27: 85-91.

[5] M. Goulter, I.R, Gentle. and G.A. Dykes, Issues in determining the factors influencing bacterial attachment; A review using the attachment of Escherichia coli to abiotic surfaces as an example. Letters of Applied Microbiology, 2009. 49, 1-7.

[6] N.P. Boks, W. Norde,. ,H. Van der Mei, H.J. Busscher, Forces involved in bacterial adhesion to hydrophilic and hydrophorbic surfaces. Microbiology. 2008. 154. 3122-3233.

[7] E. Kaczoreck, E. Chrzanowski,. A. Pijanowska and A. Olszanowski, Yeast and bacterial cell hydrophobicity and hydrocarbon biodegradation in the presence of natural surfactants. Phamnolipids and Saponins. Bioresources and Technology. 2008. 99 4285-4291.

[8] T. Baumgarten,. S. Sperling, J .,Seifert,, M. Bergen, F. ,Steiniger, ,I.Y. Wick and H. Heipieper Membrane vesicle formation as a multiple stress response mechanism enhances Pseudomonas putida DOT-T1E cell surface hydrophobicity and biofilm formation. Applied and Environmental Microbiology 2012. 17: 6217-6224.

[9] P.S. Rao,. Y. Yamada, and. K.Y. Leung, K.Y. A major catalase (Kat B) that is required for resistance to $\mathrm{HO} 2$ and phagocyte mediated killing in Edwardsiella tarda. Microbiology, (2003. 149: 2635-2644.

[10] K. Saritha,, A. Rajesh,, K. Manjulatha, O.H. Setty and S. Yenugu 2015. Mechanism of antibacterial action of the ethanolic extracts of Hemidesmus indicus (L) $\mathrm{R}$. Br ex Schult, Leucas aspera (Wild, Plumbago zeylanica and Tridax procumbens (L). R. Br. Ex. Schult. Frontiers in Microbiology, 6: 577.

[11] M. Lemos, A. Borges,. J Teodosio,,, ,P. Araujo, F. Mergulhao,, I. Melo, and M. Simoes The effect of ferulic and salicylic acids on
Bacillus cereus and Pseudomonas fluorescens single and dual - specie biofilms. International Biodeterioration and biodegradation. 2013. 86: $42-51$.

[12] J. Fabricant and A. Farnsworth, The value of plants used in traditional medicine for drug discovery. Environmental Health Perspective. 2001. 109 (supp. 1). 69-75.

[13] S. Hsieh, S. Hwang, k. Kim and S. Kim.. Investigation of the potential inhibition of UV-A enhanced toxicity and the potential inhibition of catalase by phthalate exposed to UV-A . Journal of Experimental Microbiology and Immunology. 2004. 12: 50-56.

[14] E. Chan., I. Kuang, .A. . Lau, and , J Wang, (2010). Antisense mRNA method as an alternative to generate a catalase double knock out phenotype in Escherichia coli kat G mutant. Journal of Experimental Microbiology and Immunology. 14. 127-134.

[15] C.C. Adonu,. C.C.. Eze, M.E. Ugwoeze, and K.O. Ugwu, Comparative study of Cassytha filiformis and Cleistopholis patens for antimicrobial activities. World Journal of Pharmacy and Pharmaceutical Sciences. 2013; 2 (30): 1434-1445.

[16] B.B. N' Guessan, K, Dosso, B.N. Gnangoran, P. Amoateng, and B.N. Asiedu- Gyekye. Antibacterial and antispasmodic activities of dichloromethane fraction of ethanol extract of stem bark of Piliostigma reticulatum. Journal of Pharmacy and Bioallied Sciences. 2015. 7 (2): 128-135.

[17] D.C. Okechukwu,, M.A, Momoh,. and C.O.. Esimone, Evaluation of anticandidal activity of methanolic leaf extract of Cleistopholis patens on Candida $s p$ isolated from stage II HIV patient. African Health Science. 2015. 15 (3): 789-796.

[18] M.A. Aderogba, E.K,. Okoh,, I..N. , Okeke., A.O. Olajide, and A.O. Ogundaini. Antimicrobial and antinflammatory effect of Piliostigma reticulatum leaf extract. International Journal of Pharmacology. 2006. (2): $70-74$.

[19] A. Zerbo, J,. Koudou,., N. Ouedraogo, R. Ouedraogo, and F Guissou Antioxidant and antibacterial activity of Piliostigma reticulatum (OC) Hochst extracts. African Journal of Biotechnology. 2010. 9 (33): 5407-5411.

[20] A. Brauner,, N, Shoresh,, N. Fridman, Q. BalabanAn experimental framework for quantifying bacterial tolerance. Biophysical Journal. 2017. . 112 (12). 2664-2671

[21] B. Ferro,, J.V. EIngen. M.. Wattenberg, D.V Soolingen, and J.W Mouton, Time-kill kinetics of antibiotics active against rapidly growing Mycobacteria. Journal of Antimicrobial Chemotherapy. 2015.. 70 (3): 811-817.

[22] Y.A. Shami, and A. Almasri. Bacteriostatic and bacteriocidal activity of Deer musk on multidrug reisitant bacteria. Pakistan Journal of Biological Sciences. 2018. 21(7): 331-339.

[23] D. Anderson The ways in which bacteria resist antibiotics; A global threat of antibiotic resistance. Exploring roads towards concerted action. 2004. A multidisciplinary meeting at the DAG HAMMRSKJOLD Foundation, Uppsala, Sweden (Background document).

[24] J.N. Rosenberg, G.A. Oyler, L. Wilkinson,and M.J. Betenbaugh,. A green light for engineered algae: redirecting metabolism to fuel, a biotechnology revolution. Current Opinion in Biotechnology.2008. 19 (5) $430-436$.

[25] .P. Lather., A.K. Mohanty, J. .Pankaj and A.K. Garsa, Contribution of Cell Surface Hydrophobicity in the Resistance of Staphylococcus aureus against Antimicrobial Agents. Biochemistry Research International. 2016, Article ID 1091290, 5 pages

[26] S. Nomura, A. Huroiwa, and A. Nagayama. Changes in hydrophobicity and charges of Staphylococcus aureus treated with Sub-MIC of antibiotics and their effects on Chemiluminiscence response of Phagocytic cells. Chemotherapy, 1995. 41.77-81

[27] M.A. Kohanski,, D.J. Dwyer, B. Hayete,, C.A. Lawrence, and J.J. Collins. A common mechanism of cellular death induced by bactericidal antibiotics. Cell. 2007. 130: 797-810.

[28] I. Dwyer, ,P.A. Belenky, J.H. Yang,.. C. MacDonald, J.D. Martell, M.M. Takanashi. Antibiotics induce redox -related physiological alterations as part of their lethality; 2014. PNAS. 
- Dr Adetoyosi O. Daniels is a PhD Holder in Medical and pathogenic Microbiology from The Ekiti State University, Ado Ekiti, Ondo State, Nigeria. She was born in 1969 at Ile Oluji, Ondo State of Nigeria

She has vast interest in medical research. She is currently the Dean of College of Natural and Applied Sciences of Achievers University formerly the Head of Department of Biological Sciences, Achievers University, Owo, Ondo State, Nigeria. Dr. Daniels also teaches undergraduate and post graduate courses in the department of Biological Sciences.

Dr Daniels is a member of The Nigerian Society for Microbiologist and Biotechnology Society of Nigeria.

- Dr Taye Temikotan is a PhD Holder in Plant pathology and Genetics from the Federal University of Technology, Akure, Ondo State, Nigeria.. He is currently the Head of Department of Biological Sciences of Achievers University, Owo, Ondo State, Nigeria. He teaches undergraduate and Post graduate courses in the Department of Biological Sciences of Achievers University, Owo, Ondo State, Nigeria.

- Mr David .A. Ibiyemi is the Head of Department of Chemical Sciences with a specialty in Biochemistry. He also teaches undergraduate and post graduate courses in the department of Chemical Sciences of Achievers University, Owo, Ondo State, Nigeria. 